\title{
Nursing and Fuzzy Logic: an Integrative Review ${ }^{1}$
}

\author{
Rodrigo Jensen ${ }^{2}$ \\ Maria Helena Baena de Moraes Lopes ${ }^{3}$
}

This study conducted an integrative review investigating how fuzzy logic has been used in research with the participation of nurses. The article search was carried out in the CINAHL, EMBASE, SCOPUS, PubMed and Medline databases, with no limitation on time of publication. Articles written in Portuguese, English and Spanish with themes related to nursing and fuzzy logic with the authorship or participation of nurses were included. The final sample included 21 articles from eight countries. For the purpose of analysis, the articles were distributed into categories: theory, method and model. In nursing, fuzzy logic has significantly contributed to the understanding of subjects related to: imprecision or the need of an expert; as a research method; and in the development of models or decision support systems and hard technologies. The use of fuzzy logic in nursing has shown great potential and represents a vast field for research.

Descriptors: Nursing; Fuzzy Logic; Review Literature as Topic.

\footnotetext{
${ }^{1}$ Paper extracted from Master's Thesis "Desenvolvimento e avaliação de um programa computacional baseado em lógica fuzzy para verificação da acurácia diagnóstica de estudantes de enfermagem" presented to Programa de Pós Graduação, Universidade Estadual de Campinas, SP, Brazil. Supported by FAPESP, process \# 08/51800-9.

2 RN, Doctoral Student in Nursing, Faculdade Ciências Médicas, Universidade Estadual de Campinas, SP, Brazil. E-mail: rodrigojensen@yahoo.com.br.

${ }^{3}$ RN, Ph.D. in Genetics and Molecular Biology, Associate Professor, Faculdade de Ciências Médicas, Universidade Estadual de Campinas, SP, Brazil. E-mail: mhbaenaml@yahoo.com.br.
}

Corresponding Author:

Maria Helena Baena de Moraes Lopes

Universidade Estadual de Campinas. Faculdade de Ciências Médicas.

Departamento de Enfermagem.

Rua Tessália Vieira de Camargo, 126

Bairro Barão Geraldo

CEP: 13084-971 Campinas, SP, Brasil

E-mail: mhbaenaml@yahoo.com.br 


\section{Enfermagem e lógica fuzzy: uma revisão integrativa}

Este estudo teve como objetivo realizar revisão integrativa, investigando como a lógica fuzzy tem sido utilizada em pesquisas com participação de enfermeiros. A busca dos artigos foi realizada nas bases de dados CINAHL, Embase, Scopus, MEDLINE e PubMed, sem intervalo de anos especificado. Foram incluídos artigos na língua portuguesa, inglesa e espanhola; com temática relacionada à enfermagem e à lógica fuzzy, e autoria ou participação de enfermeiros. A amostra final foi de 21 artigos, de oito países. Para análise, os artigos foram distribuídos nas categorias: teoria, método e modelo. $\mathrm{Na}$ enfermagem, a lógica fuzzy tem contribuído significativamente para a compreensão de temas relativos à imprecisão ou à necessidade do especialista, como método de pesquisa e no desenvolvimento de modelos ou sistemas de apoio à decisão e de tecnologias duras. O uso da lógica fuzzy, na enfermagem, tem demonstrado grande potencial e representa vasto campo para pesquisas.

Descritores: Enfermagem; Lógica Fuzzy; Literatura de Revisão como Assunto.

\section{Enfermería y lógica fuzzy: una revisión de integradora}

Este estudio tuvo como objetivo realizar una revisión integradora investigando como la lógica fuzzy ha sido utilizada en investigaciones con participación de enfermeros. La búsqueda de los artículos fue realizada en las bases de datos CINAHL, Embase, SCOPUS, Medline y PubMed, sin especificar un intervalo de años determinado. Fueron incluidos artículos en los idiomas: portugués, inglés y castellano; con una temática relacionada a la enfermería y a la lógica fuzzy; y con autoría o participación de enfermeros. La muestra final fue de 21 artículos, de ocho países. Para el análisis, los artículos fueron distribuidos en las categorías: teoría, método y modelo. En la enfermería, la lógica fuzzy ha contribuido significativamente para la comprensión de temas relativos a la imprecisión o a la necesidad del especialista, como método de investigación y en el desarrollo de modelos o sistemas de apoyo a la decisión y de tecnologías duras. El uso de la lógica fuzzy en la enfermería ha demostrado gran potencial y representa un vasto campo para investigaciones.

Descriptores: Enfermería; Lógica Difusa; Literatura de Revisión como Asunto.

\section{Introduction}

The concept of dichotomy is present in our education, philosophy and science. Even though the Boolean logic (yes - no; true - false) is efficacious in binary quantification, its limitation and non-compatibility with human reality is evident. The notion of dichotomy is simple, limited and not realistic because its concepts do not have clear boundaries ${ }^{(1)}$.

The principle of dichotomy or the Aristotelian perspective regarding the description of world has been challenged in philosophy and in logic. The concept of three values proposed by Lukasiewicz was one of the first attempts to abandon the dichotomy supremacy. Fuzzy logic, in turn, introduced the gradual transition of the element between sets, which helps us to understand the concepts found in the real world, concepts where "yes - no" are superficial and restrictive ${ }^{(1)}$.

The theory of fuzzy logic was published in 1965 by L. A. Zadeh, a professor in the Department of Electrical Engineering and Computer Science at the University of California, Berkeley. As opposed to binary logic, Zadeh proposed the use of degrees of membership in fuzzy set theory, which permits an element to partially belong to a set. Another characteristic of fuzzy logic was the possibility to use natural language when dealing with imprecision, approximating human intuition ${ }^{(2)}$. 
If we assume that $U$ is a set that represents the universe, a fuzzy subset $A$ of $U$ is associated with a characteristic function $\mu_{A}: U \rightarrow[0,1]$, which is generally called a membership function. The idea is that for each element $\mathrm{x} \in \mathrm{U}, \mu_{\mathrm{A}}(\mathrm{x})$ indicates the degree to which $\mathrm{x}$ is a member of the set $A$.

Let us suppose we have information concerning a patient with acute pain. In traditional logic this information is included in only two sets "with acute pain" or "without acute pain". In the logic of fuzzy sets, we can establish degrees of membership of pain that are near to the sets of "strong acute pain", "moderate acute pain" or "mild acute pain" (3).

The idea of degree of membership also allows the interpretation of ancient concepts. The concepts of health and disease, for instance, are considered opposites, where disease is the absence of health and vice-versa. Hence, the existence of health and disease in the same individual is contradictory in traditional logic; these concepts are complementary in fuzzy logic(4).

Much more than a philosophical view of concepts, fuzzy logic has been applied in several areas of science and in the development of various types of computer systems, controllers of means of transportation, and consumer products such as appliances, among others. Artificial intelligence programs and decision support programs became areas where fuzzy logic is frequently employed.

Fuzzy logic has been used in the medical field for several years in studies applied to biomedical engineering, expert systems, diagnosis systems, and in epidemiological models ${ }^{(5)}$.

Given the preceding discussion, this integrative literature review searched studies that relate nursing to fuzzy logic. Therefore, we investigated how fuzzy logic has been applied in the nursing field and in which domains.

\section{Methods}

The integrative review method helps the researcher to summarize theoretical and empirical literature concerning a specific subject. An integrative review involves some steps that need to be followed(6). The steps established for this study are presented as follow.

\section{Step 1 - Problem identification}

Fuzzy logic has proven and effective applicability for data involving imprecision and in fields related to artificial intelligence technology. In the medical field, fuzzy logic has been discussed with a focus on technology. But, how have nurses applied fuzzy logic in the scientific development of nursing and in which domains? How long has fuzzy logic been discussed in nursing? Nurses from which countries have used it?

\section{Step 2 - Literature search}

The following databases were searched: CINAHL, Embase, SCOPUS, Medline and the National Library of Medicine in PubMed. Additionally, a manual search was performed for papers cited in other studies but not identified in these databases. The descriptors of the Medical Subject Headings (MeSH) and the Boolean operator $A N D$ were used, resulting in the following combinations: Nursing and Fuzzy Logic, Nurses and Fuzzy Logic. The descriptors were used in English, Portuguese and Spanish.

A time limit for publication was not established, that is, all the papers published up to October 2009, written in Portuguese, English or Spanish were included in the study. The search was performed through the Program for Access to Electronic Information and the CAPES Electronic Portal in a university in the state of São Paulo, Brazil.

\section{Step 3 - Data Evaluation}

The studies were fully read that met the following criteria: subject related to nursing; subject related to fuzzy logic; and nurses being co-authors or participating in some step of the study.

\section{Step 4 - Data Analysis}

The studies were analyzed and grouped into categories that defined how fuzzy logic was incorporated. Three categories were established: fuzzy logic as theory (theoretical and/or philosophical research concerning fuzzy logic and its relation to nursing); fuzzy logic as a method of analysis (methods of data analysis that use fuzzy logic); fuzzy logic as a model (development of models, computer programs, equipments and technological resources).

\section{Step 5 - Presentation}

A synthesis of the findings is presented in a figure and analysis was performed based on the established categories.

\section{Results}

A total of 49 papers were identified in the databases. Of these 29 were excluded: four did not meet the 
language criteria (three were written in Chinese and one in Italian) and 25 did not meet the inclusion criterion in the evaluation of data stage: the subject of eight papers was not related to nursing, the subject of 22 was not related to fuzzy logic and the authorship or participation of nurses were not identified in 11 papers. It is important to mention that some papers failed to meet more than one inclusion criterion. One paper not found in the databases was included in the study because it was cited by other two studies and met the inclusion criteria. Hence, 21 were analyzed.

A synthesis of the obtained results is presented in Figure 1. The author with the greatest number of publications has four papers related to the subject (Im EO). The papers were published over a period of 16 years (1993-2009).

The studies originated in eight countries: Brazil, the United States, the United Kingdom, New Zealand, Spain, Northern Ireland, Greece, and Taiwan, though these are most concentrated in the United States and the United Kingdom.

Among the categories established in this study, most of the papers used logic fuzzy as a model $(n=13)$. Nurses were the authors in $76.1 \%(n=16)$ of the publications, and in the remainder they participated as collaborators in only one stage, generally in data collection.

\begin{tabular}{|c|c|c|c|c|c|c|}
\hline Authors & Title & Periodical & Year & Country & Category & $\begin{array}{l}\text { Type of nurses' } \\
\text { participation }\end{array}$ \\
\hline $\begin{array}{l}\text { Lopes MHBM, Ortega NRS, } \\
\text { Massad E, Marin HF }\end{array}$ & $\begin{array}{l}\text { Model for differential nursing } \\
\text { diagnosis of alterations in urinary } \\
\text { elimination based on fuzzy logic }\end{array}$ & $\begin{array}{l}\text { Computers, } \\
\text { Informatics and } \\
\text { Nursing }\end{array}$ & 2009 & Brazil & Model & Authorship \\
\hline $\begin{array}{l}\text { Anderson D, Luke RH, Keller JM, } \\
\text { Skubic M, Rantz M, Aud M }\end{array}$ & $\begin{array}{l}\text { Linguistic summarization of video } \\
\text { for fall detection using voxel person } \\
\text { and fuzzy logic }\end{array}$ & $\begin{array}{l}\text { Computer Vision } \\
\text { and Image } \\
\text { Understanding }\end{array}$ & 2009 & $\begin{array}{l}\text { The United } \\
\text { States }\end{array}$ & Model & Authorship \\
\hline Blackwood B & $\begin{array}{l}\text { Commentary: Nemoto T et al. } \\
\text { (1999). Automatic control of } \\
\text { pressure support mechanical } \\
\text { ventilation using fuzzy logic }\end{array}$ & $\begin{array}{l}\text { Nursing in Critical } \\
\text { Care }\end{array}$ & 2008 & $\begin{array}{l}\text { Northern } \\
\text { Ireland }\end{array}$ & Theory & Authorship \\
\hline $\begin{array}{l}\text { Wang WL, Chang HJ, Liu AC, } \\
\text { Chen YW }\end{array}$ & $\begin{array}{l}\text { Research into care quality criteria } \\
\text { for long-term care institutions }\end{array}$ & $\begin{array}{l}\text { Journal of Nursing } \\
\text { Research }\end{array}$ & 2007 & Taiwan & Method & Authorship \\
\hline Christensen M, Hewitt-Taylor J & $\begin{array}{l}\text { From expert to tasks, expert } \\
\text { nursing practice redefined? }\end{array}$ & $\begin{array}{l}\text { Journal of Clinical } \\
\text { Nursing }\end{array}$ & 2006 & $\begin{array}{l}\text { The United } \\
\text { Kingdom }\end{array}$ & Theory & Authorship \\
\hline Christensen M, Hewitt-Taylor J & Defining the expert ICU nurse & $\begin{array}{l}\text { Intensive and } \\
\text { Critical Care } \\
\text { Nursing }\end{array}$ & 2006 & $\begin{array}{l}\text { The United } \\
\text { Kingdom }\end{array}$ & Theory & Authorship \\
\hline Im EO, Chee W & $\begin{array}{l}\text { Evaluation of the decision support } \\
\text { computer program for cancer pain } \\
\text { management }\end{array}$ & $\begin{array}{l}\text { Oncology Nursing } \\
\text { Forum }\end{array}$ & 2006 & $\begin{array}{l}\text { The United } \\
\text { States }\end{array}$ & Model & Authorship \\
\hline $\begin{array}{l}\text { Im EO, Chee W, Lim HJ, Bender } \\
\text { M, Tsai HM, Yang SO, et al }\end{array}$ & $\begin{array}{l}\text { Recruitment of oncology nurses for } \\
\text { internet research: Issues and future } \\
\text { directions }\end{array}$ & $\begin{array}{l}\text { Oncology Nursing } \\
\text { Forum }\end{array}$ & 2006 & $\begin{array}{l}\text { The United } \\
\text { States }\end{array}$ & Model & Authorship \\
\hline $\begin{array}{l}\text { Belal SY, Taktak AFG, Nevill A, } \\
\text { Spencer A }\end{array}$ & $\begin{array}{l}\text { An intelligent ventilation and } \\
\text { oxygenation management system } \\
\text { in neonatal intensive care using } \\
\text { fuzzy trend template fitting }\end{array}$ & $\begin{array}{l}\text { Physiological } \\
\text { Measurement }\end{array}$ & 2005 & $\begin{array}{l}\text { The United } \\
\text { Kingdom }\end{array}$ & Model & Collaboration \\
\hline $\begin{array}{l}\text { Liatsos C, Hadjileontiadis LJ, } \\
\text { Theocharis S, Petridou E, Margeli } \\
\text { A, Skaltsas S, et al }\end{array}$ & $\begin{array}{l}\text { Using higher-order crossings } \\
\text { to distinguish liver regeneration } \\
\text { indices in hepatectomized diabetic } \\
\text { and non-diabetic rats }\end{array}$ & $\begin{array}{l}\text { Journal of } \\
\text { Gastroenterology } \\
\text { and Hepatology }\end{array}$ & 2005 & Greece & Method & Authorship \\
\hline $\begin{array}{l}\text { Marques IR, Barbosa SF, Basile } \\
\text { ALO, Marin HF }\end{array}$ & $\begin{array}{l}\text { Decision-support guideline in } \\
\text { obstetrical nursing: application of } \\
\text { Fuzzy Logic technique }\end{array}$ & $\begin{array}{l}\text { Brazilian Journal of } \\
\text { Nursing }\end{array}$ & 2005 & Brazil & Model & Authorship \\
\hline $\begin{array}{l}\text { Chase JG, Agogue F, Starfinger } \\
\text { C, Lam Z, Shaw GM, Rudge AD, } \\
\text { et al. }\end{array}$ & $\begin{array}{l}\text { Quantifying agitation in sedated } \\
\text { ICU patients using digital imaging }\end{array}$ & $\begin{array}{l}\text { Computer Methods } \\
\text { and Programs in } \\
\text { Biomedicine }\end{array}$ & 2004 & $\begin{array}{l}\text { New } \\
\text { Zealand }\end{array}$ & Model & Collaboration \\
\hline
\end{tabular}

(continue...) 
(continuation)

\begin{tabular}{|c|c|c|c|c|c|c|}
\hline Authors & Title & Periodical & Year & Country & Category & $\begin{array}{c}\text { Type of nurses' } \\
\text { participation }\end{array}$ \\
\hline $\begin{array}{l}\text { Chase JG, Starfinger C, Lam Z, } \\
\text { Agogue F, Shaw GM }\end{array}$ & $\begin{array}{l}\text { Quantifying agitation in sedated } \\
\text { ICU patients using heart rate and } \\
\text { blood pressure }\end{array}$ & $\begin{array}{l}\text { Physiological } \\
\text { Measurement }\end{array}$ & 2004 & $\begin{array}{l}\text { New } \\
\text { Zealand }\end{array}$ & Model & Collaboration \\
\hline Im EO, Chee W & $\begin{array}{l}\text { Decision support computer program } \\
\text { for cancer pain management }\end{array}$ & $\begin{array}{l}\text { Computers, } \\
\text { Informatics and } \\
\text { Nursing }\end{array}$ & 2003 & $\begin{array}{l}\text { The United } \\
\text { States }\end{array}$ & Model & Authorship \\
\hline Im EO, Chee W & Fuzzy logic and nursing & Nursing Philosophy & 2003 & $\begin{array}{l}\text { The United } \\
\text { States }\end{array}$ & Theory & Authorship \\
\hline $\begin{array}{l}\text { Innocent PR, John RI, Garibaldi } \\
\text { JM. }\end{array}$ & $\begin{array}{l}\text { The fuzzy medical group at } \\
\text { the centre for computational } \\
\text { intelligence }\end{array}$ & $\begin{array}{l}\text { Artificial Intelligence } \\
\text { in Medicine }\end{array}$ & 2001 & $\begin{array}{l}\text { The United } \\
\text { Kingdom }\end{array}$ & Model & Collaboration \\
\hline Kerfoot K & $\begin{array}{l}\text { TIQ (Technical IQ)_a survival skill } \\
\text { for the new millennium }\end{array}$ & Nursing Economics & 2000 & $\begin{array}{l}\text { The United } \\
\text { States }\end{array}$ & Theory & Authorship \\
\hline Rolfe G & $\begin{array}{l}\text { Science, abduction and the fuzzy } \\
\text { nurse: an exploration of expertise }\end{array}$ & $\begin{array}{l}\text { Journal of Advanced } \\
\text { Nursing }\end{array}$ & 1997 & $\begin{array}{l}\text { The United } \\
\text { Kingdom }\end{array}$ & Theory & Authorship \\
\hline Bosque EM & $\begin{array}{l}\text { Symbiosis of nurse and machine } \\
\text { through fuzzy logic: improved } \\
\text { specificity of a neonatal pulse } \\
\text { oximeter alarm }\end{array}$ & $\begin{array}{l}\text { Advances in } \\
\text { Nursing Science }\end{array}$ & 1995 & $\begin{array}{l}\text { The United } \\
\text { States }\end{array}$ & Model & Authorship \\
\hline Bosque EM & $\begin{array}{l}\text { Pulse oximetry and intuition in the } \\
\text { neonatal intensive care unit }\end{array}$ & $\begin{array}{l}\text { Critical Care } \\
\text { Nursing Clinics of } \\
\text { North America }\end{array}$ & 1995 & $\begin{array}{l}\text { The United } \\
\text { States }\end{array}$ & Model & Authorship \\
\hline $\begin{array}{l}\text { Ruiz R, Borches D, González A, } \\
\text { Corral J }\end{array}$ & $\begin{array}{l}\text { A new sodium-nitroprusside- } \\
\text { infusion controller for the regulation } \\
\text { of arterial blood pressure }\end{array}$ & $\begin{array}{l}\text { Biomedical } \\
\text { Instrumentation and } \\
\text { Technology }\end{array}$ & 1993 & Spain & Model & Collaboration \\
\hline
\end{tabular}

Figure 1 - Distribution of papers on fuzzy logic according to authorship, title, periodical, year of publication, country of origin, category of analysis and type of nurses' participation - October 2009

\section{Fuzzy Logic as Theory}

Six papers discuss theoretical aspects of fuzzy logic based on other studies and on the literature in general. Authors $^{(3)}$ indicate a relationship between fuzzy logic and nursing, suggesting it agrees with the epistemological view of nursing (correspondence, coherence and pragmatism) and with four important philosophical trends (post-empiricism, pragmatism, feminism and postmodernism). Additionally, nursing phenomena are characterized by complexity, ambiguity, and imprecision, similar to fuzzy logic.

Considering the use of computer innovations in professional practice, systems based on fuzzy logic apparently obtain better performance than experts in the decision-making process and in describing how this process occurs $^{(7)}$. Hence, fuzzy logic could be employed to help experts to explain how they establish their decisions and even to attribute weight to each of the fuzzy rules used in the process. Fuzzy logic would help experts to verbalize their decision-making process and this way of understanding could be transmitted in the teachinglearning process from professors to students ${ }^{(7)}$.
The application of fuzzy logic in the artificial intelligence field is seen as having great potential for future technologies to be developed in hospital environments ${ }^{(8)}$. Expert nurses are 'expensive products'. Hence, the creation of protocols has been an alternative intended to replace nurse experts. Even though the protocols can be used by technically competent professionals, protocols are not able to provide an individualized and holistic care, which is closely related to the intuition of expert nurses ${ }^{(9-10)}$.

Fuzzy logic reflects the expert nurses' decisionmaking process. Through fuzzy logic one can provide evidence that the decision-making process of experts is performed through an intuitive judgment (various parameters are considered), that experts do not strictly follow the rules but consider a set of information to perceive the situation as a whole ${ }^{(9-10)}$.

The use of protocols for ventilator weaning, for instance, is a rigid approach and the decision to wean ventilatory devices requires a complexity greater than what protocols present. In such situations, fuzzy logic could be applied(11). 


\section{Fuzzy logic as method}

One of the methods of analysis found in the studies based on fuzzy logic was c-means, which permits grouping data to estimate each cluster center, the distance among data to the center, and the distance between the centers of two clusters ${ }^{(12)}$.

Another method was the Fuzzy Delphi Method, which combines the Delphi method with fuzzy logic. The method was used for collective decision-making processes used by experts to reach consensus where fuzzy logic resolves the issue of a lack of unanimity among experts ${ }^{(13)}$.

\section{Fuzzy logic as model}

Fuzzy logic can be used in the development of systems with different purposes such as to control infusion(14), oximeters(15-16), to aid nurses in decisionmaking concerning patients' pain ${ }^{(17-18)}$, to measure patient agitation using a digital image processor ${ }^{(19)}$ and heart beat variation, blood systolic pressure and variability of blood pressure(20), to support decision-making in the management of ventilation and oxygenation(21), and to detect falls ${ }^{(22)}$. It can also be used in the development of decision-making models for nurses who use nursing knowledge considering the nursing process, the complexity of the context, and the degree of intensity of nurse/patient interactions ${ }^{(23)}$, support for decisionmaking concerning amniotomy in primiparae pregnant woman(24), and the differential nursing diagnosis of alterations of urinary elimination ${ }^{(25)}$.

The application of fuzzy logic can have different objectives in the development of systems. It can be used to model the basis of algorithm rules, capturing the knowledge of experts and dealing with uncertainty(14), characterize the variables of a system with fuzzy sets ${ }^{(15-}$ 16), administer databases with the opinions of experts ${ }^{(17)}$, classify responses detected by systems ${ }^{(19-20)}$, detect and remove data that do not reflect a real situation, and follow-up trends of parameter evolution(21). It can also be applied to model concepts and uncertainty expressed in linguistic(23) terms in the development of models because fuzzy logic allows the use of natural language and expressions such as "always", "frequently", "sometimes", "rarely" or "never", thus aiding in the decision-making process of nurses in the face of an intervention ${ }^{(24)}$ or diagnosis ${ }^{(25)}$.

The studies present good results in relation to systems based on fuzzy logic when comparing these to previously used traditional methods $(14-16,19-20)$ or demonstrating their reliability ${ }^{(26)}$.

\section{Discussion}

The relationship established between fuzzy logic and nursing is recent. The first study with nurse authorship dates from 1995. However, the most recent study was conducted in Brazil whose main author is a nurse.

An important diversity of countries and authors applying fuzzy logic was identified. We can relate this finding to the broad and relevant contribution of fuzzy logic when applied to nursing and other domains in the health field. It shows how fuzzy logic is disseminated in research and how generic its application can be. The predominance of studies in the English language was expected, since fuzzy logic originated in the United States.

There is a predominance of nurse authorship $(16 / 21)$. However, the number of studies applying fuzzy logic in the scientific development of nursing is still inexpressive considering its potential usefulness.

Fuzzy logic was used as a theoretical concept in several discussions concerning subjects such as technological innovation, nursing phenomena, and the relevance of expert nurses. Fuzzy logic has the potential to be applied in the study of philosophical concepts regarding nursing practice.

The methods of data analysis based on fuzzy logic improve proven accepted methods such as the Delphi technique, very frequently used in research. The scarcity of studies is possibly explained by the fact that few nurses are familiar with the use of fuzzy logic in research methods.

The use of fuzzy logic as a model was the most expressive among the studies found (13/21). This finding may be explained by the fact that fuzzy logic originated in the exact sciences where most technological development takes place. The use of fuzzy logic was predominantly found in studies developing models and computer programs, effectively contributing to the development of hard technologies. The products developed with fuzzy logic are mainly used in units that provide highly complex care.

There seems to be a strong application of fuzzy logic related to the decision-making process, a subject frequently discussed in nursing ${ }^{(27)}$. Nonetheless, the fact that few studies indicate that authors continued their investigations draws our attention.

The studies are recent and the interest in fuzzy logic seems to be growing among researchers. There is a need to improve the developed models, testing them in other contexts and with other populations in order to put 
them in practice and promote professional development, and improve nursing care delivery.

\section{Conclusion}

Based on the studied papers we conclude that fuzzy logic has been used by nurses mainly in the decisionmaking process and in the development of models. Fuzzy logic is consistent with the epistemological and philosophical view of nursing, enabling nurses to deal with complex, ambiguous and inaccurate nursing phenomena. Even though the use of fuzzy logic as a methodological resource is promising, it has been little explored.

The use of fuzzy logic in nursing research began only recently. However nurses from different countries and continents have conducted studies using fuzzy logic showing that interest in the subject is universal.

Given the preceding discussion, we suggest the development of further research and application of fuzzy logic in theoretical and methodological aspects or in the development of models to contribute to nursing practice.

\section{References}

1. Pedrycz W, Gomide F. Fuzzy systems engineering: toward human-centric computing. New Jersey: John Wiley \& Sons; 2007. 526 p.

2. Zadeh LA. Fuzzy sets. Inform Contr. 1965;8:338-53.

3. Im E-O, Chee W. Fuzzy logic and nursing. Nurs Philos. 2003;4(1):53-60.

4. Sadegh-Zadeh K. Fundamentals of clinical methodology:

3. Nosology. Artif Intell Med. 1999;17:87-108.

5. Ortega NRS. Aplicação da teoria dos conjuntos fuzzy a problemas da biomedicina [tese de doutorado]. São Paulo (SP): Instituto de Física/USP; 2001. 152 p.

6. Whittemore $\mathrm{R}$, Knafl $\mathrm{K}$. The integrative review: updated methodology. J Adv Nurs. 2005;52(5):546-53.

7. Rolfe G. Science, abduction and the fuzzy nurse: an exploration of expertise. J Adv Nurs. 1997;25(5):1070-5.

8. Kerfoot K. TIQ (Technical IQ) - a survival skill for the new millennium. Nurs Econ. 2000;18(1):29-31.

9. Christensen M, Hewitt-Taylor J. From expert to tasks, expert nursing practice redefined? J Clin Nurs. 2006;15(12):1531-9.

10. Christensen M; Hewitt-Taylor J. Defining the expert ICU nurse. Intensive Crit Care Nurs. 2006;22(5):301-7. 11. Blackwood B. Commentary: Nemoto T et al. (1999). Automatic control of pressure support mechanical ventilation using fuzzy logic. Nurs Crit Care. 2008; 13(3):178-9.

12. Liatsos C, Hadjileontiadis LJ, Theocharis S, Petridou E, Margeli A, Skaltsas S, et al. Using higher-order crossings to distinguish liver regeneration indices in hepatectomized diabetic and non-diabetic rats. J Gastroenterol Hepatol. 2005;20(1):126-34.

13. Wang WL, Chang HJ, Liu AC, Chen YW. Research into care quality criteria for long-term care institutions. J Nurs Res. 2007;15(4):255-64.

14. Ruiz R, Borches D, González A, Corral J. A new sodium-nitroprusside-infusion controller for the regulation of arterial blood pressure. Biomed Instrum Technol. 1993;27(3):244-51.

15. Bosque EM. Pulse oximetry and intuition in the neonatal intensive care unit. Crit Care Nurs Clin North Am. 1995;7(2):219-25.

16. Bosque EM. Symbiosis of nurse and machine through fuzzy logic: Improved specificity of a neonatal pulse oximeter alarm. Nurs Ther. 1995;18(2):67-75.

17. Im E-O, Chee W. Decision support computer program for cancer pain management. Comput Inform Nurs. 2003;21(1):12-21.

18. Im E-O, Chee W, Lim HJ, Bender M, Tsai H-M, Yang $\mathrm{S}-\mathrm{O}$, et al. Recruitment of oncology nurses for internet research: issues and future directions. Oncol Nurs Forum. 2006;33(2):249-54.

19. Chase JG, Agogue F, Starfinger C, Lam Z, Shaw $G M$, Rudge $A D$, et al. Quantifying agitation in sedated ICU patients using digital imaging. Comput Methods Programs Biomed. 2004;76(2):131-41.

20. Chase JG, Starfinger C, Lam Z, Agogue F, Shaw GM. Quantifying agitation in sedated ICU patients using heart rate and blood pressure. Physiol Meas. 2004;25(4):1037-51.

21. Belal SY, Taktak AF, Nevill A, Spencer A. An intelligent ventilation and oxygenation management system in neonatal intensive care using fuzzy trend template fitting. Physiol Meas. 2005;26(4):555-70.

22. Anderson D, Luke RH, Keller JM, Skubic M, Rantz $M$, Aud M. Linguistic summarization of video for fall detection using voxel person and fuzzy logic. Comput Vis Image Underst. 2009;113(1):80-9.

23. Innocent PR, John RI, Garibaldi JM. The fuzzy medical group in the centre for computational intelligence. Artif Intell Med. 2001;21(1-3):163-70.

24. Marques IR, Barbosa SF, Basile ALO, Marin HF. Guia de apoio à decisão em enfermagem obstétrica: aplicação da técnica da lógica fuzzy. Rev Bras Enferm. 2005;58(3):349-54. 
25. Lopes MHBM, Ortega NRS, Massad E, Marin HF. Model for differential nursing diagnosis of alterations in urinary elimination based on fuzzy logic. Comput Inform Nurs. 2009;27(5):324-9.

26. Im E-O, Chee W. Evaluation of the decision support computer program for cancer pain management. Oncol Nurs Forum. 2006;33(5):977-82.

27. Campos DCF, Graveto JMGN. The role of nurses and patient's involvement in the clinical decisionmaking process. Rev. Latino-Am. Enfermagem. 2009;17(6):1065-70. 